Ruddle

Palm Sago

Paperback Edition

May 1978

1716

$\$ 7.50$

\title{
Palm Sago
}


₹. THE EAST-WEST CENTER-officially known as the Center for Cultural and Technical Interchange Between East and West-is a national educational institution established in Hawaii by the U.S. Congress in 1960 to promote better relations and understanding between the United States and the nations of Asia and the Pacific through cooperative study, training, and research. The Center is administered by a public, nonprofit corporation whose international Board of Governors consists of distinguished scholars, business leaders, and public servants.

Each year more than 1,500 men and women from many nations and cultures participate in Center programs that seek cooperative solutions to problems of mutual consequence to East and West. Working with the Center's multidisciplinary and multicultural staff, participants include visiting scholars and researchers; leaders and professionals from the academic, government, and business communities; and graduate degree students, most of whom are enrolled at the University of Hawaii. For each Center participant from the United States, two participants are sought from the Asian and Pacific area.

Center programs are conducted by institutes addressing problems of communication, culture learning, environment and policy, population, and resource systems. A limited number of "open" grants are available to degree scholars and research fellows whose academic interests are not encompassed by institute programs.

The U.S. Congress provides basic funding for Center programs and a variety of awards to participants. Because of the cooperative nature of Center programs, financial support and cost-sharing are also provided by Asian and Pacific governments, regional agencies, private enterprise and foundations. The Center is on land adjacent to and provided by the University of Hawaii.

East-West Center Books are published by The University Press of Hawaii to further the Center's aims and programs. 


\section{Palm Sago}

\section{A Tropical Starch from Marginal Lands}

KENNETH RUDDLE

DENNIS JOHNSON

PATRICLA K. TOWNSEND

JOHN D. REES

玉 ANEAST-WEST CENTER BOOK from the East-West Technology and Development Institute

Published for the East-West Center by The University Press of Hawaii Honolulu 
Copyright (C) 1978 by East-West Center

All rights reserved. No part of this work may be reproduced or transmitted in any form or by any means, electronic or mechanical, including photocopying and recording, or by any information storage or retrieval system, without permission in writing from the publisher.

Manufactured in the United States of America

Library of Congress Cataloging in Publication Data

Main entry under title:

Palm sago.

Bibliography: $\mathrm{p}$.

Includes index.

1. Sago. I. Ruddle, Kenneth.

TP416.S3P34 338.4'7'6642 77-28981

ISBN 0-8248-0577-1

Simultaneously published by Australian National University Press, Canberra, and for the East-West Center by The University Press of Hawaii, Honolulu.

The cover photograph is of Melanau women dismantling a Metroxylon palm log raft in preparation for extracting sago (photo courtesy of the Sarawak Museum). 
This book is respectfully dedicated to Professor Joseph E. Spencer, an eclectic geographer, on his retirement. 
